education in Ukraine]. Preschool education, no. 1, pp. 6-19. [in Ukrainian].

2. Skotna, M. (2013). Matematychna osvita doshkilnykiv u Polshchi [Mathematical education of preschool children in Poland]. Youth and market, no.12(107), pp.137-142. [in Ukrainian].

3. Starchenko, V. (2005). Lohiko-matematychnyi aspekt doshkilnoi osvity [Logic-mathematical aspect of preschool education]. Preschool education, no. 7, pp. 22-23. [in Ukrainian].

4. Tatarynova, S.O. (2004). Lohiko-matematychna kompetentnist ditei starshoho doshkilnoho viku [Logical and mathematical competence of preschool children]. Actual problems of preschool and primary education in modern conditions, Kherson, pp. 59-61. [in Ukrainian].

Стаття надійшла до редакції 19.08.2019

УДК 78.071.2:784.4(477)

DOI:

Лідія Федоронько, кандидат мистецтвознавства, доцент кафедри музикознавства та фортепіано

Дрогобицького державного педагогічного університету імені Івана Франка

\title{
ВИКОНАВСЬКА РЕКОНСТРУКЦІЯ ОБРЯДІВ ЯК ОДИН 3 МЕТОДІВ ТРАНСМІСІЇ НАРОДНОЇ МУЗИЧНОЇ ТРАДИЦІї
}

У статті висвітлено особливості реконструкиії обряду обжинок як одного з механізмів трансмісії фольклору. Проаналізовано всі існуючі публікації та архівні матеріали, в яких зафіксовано локальний варіант обжинок с. Нагуєвичі Дрогобиџького району. На чій основі продемонстровано можливість відтворення обряду у науково-виконавській інтерпретації, щуо дає можливість мінімалізувати стильові втрати через вторинну форму виконання.

Ключові слова: музичний фольклор; трансмісія фольклору; реконструкиія обряду; пісенні наспіви; народновиконавська манера.

Jim. 8.

Lidiya Fedoronko, Ph.D. (Art Studies), Associate Professor of the Musicology and Piano Department Drohobych Ivan Franko State Pedagogical University

\section{EXECUTIVE RECONSTRUCTION OF RITES AS ONE OF THE TRANSMISSION METHODS OF THE NATIONAL MUSICAL TRADITION}

The tradition remains relevant as a law of continuity, without which there can be no development of culture. In a globalized world, there is a threat of folklore disappearance in its local styles and variants. Therefore, it is necessary to find ways of the restoration and preservation of folk culture, in particular rites that occupy an important place in the genre system of Ukrainian folklore.

Ritual folklore is closely connected with the environment of existence, with the way of life of the community, the level of its economic and production status. With the change of these factors, the ritual sphere is changing or fading. One of the factors preventing the complete disappearance of local variants is the reconstruction of ceremonies, the most important components of which, besides composition, can be called verbal-musical element.

Based on existed publications and archival materials, a reconstruction of the reaping rites of village Nahuyevychi, Drohobych district (ethnographic district - Boyko Pidhirya) was done. The basic methodical techniques, which allow preserving the local style as much as possible, are derived and described. This is primarily due to the vocal and instrumental manner of execution, and the use of ethnographic elements.

Reproduction of the rite lives in the form of reconstruction, using fixed forms of conservation, makes it possible to actualize interesting patterns of local folklore in the new conditions.

Keywords: musical folklore; transmission of folklore; reconstruction of the rite; singing songs; folk-style manner.

П остановка проблеми. Сьогодні, в епоху глобалізації, яка стрімко набирає обертів в Україні, особливо гостро постає питання збереження традиції та ії місця у культурі. В умовах дискусії про консервативну i модерну складову в структурі останньої залишається актуальним розуміння традиції як передачі досвіду, звичаїв, культурних надбань із покоління в покоління, як закон спадкоємності, без якої не може бути розвитку культури. Можна згодитися зі словами Едварда Шилза, що традиція, якщо ії визнано, не менш жива й важлива 

НАРОДНОЇ МУЗИЧНОЇ ТРАДИЦІЇ

для тих, хто визнає іiі, ніж будь-яка інша частина їхної діяльності та поглядів. Традиція - це минуле в теперішньому, але вона не меншою мірою частина теперішності, ніж будь-яка найсвіжіша новація [Цит. за 8, 5].

Про виховний потенціал фольклору як важливої складової національної культури, про його роль національного ідентифікатора, говориться постійно і незмінно, однак, як ніколи в попередні часи, суспільство близько підійшло до тієї межі, за якою знаходиться прірва занепаду тисячолітніх надбань народної нематеріальної культури. У випадку музичного фольклору, то, звичайно, збережено багато записів, народна музика фіксується, i особливо сьогодні, коли постала виразна загроза зникнення локальних стилів, або, у кращому випадку, їх уніфікація. Однак сама фіксація того, що ще залишилося, не вирішує проблеми, тому що фольклор повинен жити самодостатнім життям, мало того, він повинен мати динаміку, тобто активно реагувати на сучасність, бути співзвучним із сучасною свідомістю членів соціуму, зберігати свій національний профіль, іншими словами, виконувати споконвічно відведену йому функцію. Особливо гостро постає проблема збереження обрядового фольклору, який тісно пов'язаний зі способом життя середовища, i зі зміною цього способу він втрачає свою актуальність та розуміння змісту і символіки. У зв’язку з цим проблема утривалення його в часі $\mathrm{i}$ просторі, зокрема, тих цінних зразків, які репрезентують локальні стилі, надалі продовжує існувати.

Аналіз основних досліджень та публікацій. Проблематикою трансмісії фольклору пронизані статті та монографії відомої вченої Софії Грици. Однак основними iï працями, які висвітлюють питання актуалізації та динаміки фольклору в сучасному соціумі можна назвати ті дослідження, в яких авторка основний акцент робить на соціологічному аспекті народної творчості, що дає можливість окреслити траєкторію руху цієї частини культури від іiї становища в “класичному” статусі через сучасність до майбутнього. Зокрема, це статті “Відродження народнопісенних джерел” [1, 198 - 205], "Проблеми репрезентації фольклору на святі народної творчості” [1, 205 217]; “Народний професіоналізм” [2, 137 - 168], “Во ім'я збереження фольклору” [2, $174-178]$ та інші.

Питання актуалізації пісенно-інструментального фольклору в його вторинному варіанті порушує М. Хай у своїй монографії “Музично-інструментальна культура українців (фолкльорна традиція)”, в якій автор виводить поняття новітньої науково- виконавсько-реконструктивної форми фольклоризму як перспективної і такої, що найбільш адекватно передає звукоідеал і сутність традиційної музики в сучасних умовах $[8,17]$.

Окреслені вітчизняними етномузикологами питання потребують поглиблення їх розгляду та практичної конкретизації на локальному фольклорному матеріалі. Це визначає мету статті, яка полягає у формуванні варіанту методики проведення реконструкиії як одного 3 механізмів збереження народномузичної традиції, на прикладі обряду бойківських обжинків.

Виклад основного матеріалу. В сучасних умовах життя суспільства кардинально змінилася структура середовища, в якому творилася народна культура. Відомо, що основна диференціація типів середовища як осередку народної культури, пролягає між сільським та міським, урбанізованим, видом. Сьогодні межа між цими двома типами розмивається, змінюється їх традиційна структура, і особливо ці зміни стосуються першого типу. Відтак трансформуються зв'язки між сільською та міською культурою і їх взаємодія [2, 52 - 75]. Внаслідок активізації міграційних процесів, внутрішніх і зовнішніх, відбувається зміна структури як всієї карти сільських громад, так і внутрішньої соціальної структури самих громад. В минулому традиційні, закриті або відносно закриті, середовища більшою мірою робили акцент на локальний фольклор, зберігаючи власний стиль і власний репертуар, натомість сьогодні відбувається трансформація цієї системи. Носії автентичного фольклору відходять, у більшості випадків не передаючи свій досвід і надбання наступним поколінням, так як це здійснювалося завжди. Утворюється пустка, вакуум, який повинен заповнитись. До цих природних причин додається активне засилля масовою популярною музикою, часто не найкращого гатунку, що ще більше віддаляє людей, здебільшого молодого віку, від власної традиційної культури.

В цих умовах видається важливим виявити, які механізми здатні зберегти традиційну музику і передати іiі наступним поколінням в сучасних умовах, що є важливою умовою іiї продовження та збереження. У фольклористиці передавання фольклору або фольклорного смислу називається фольклорною трансмісією, яка може здійснюватися горизонтально (в одній часовій площині) або вертикально (в різночасових площинах). Хоча $є$ різні механізми трансмісії, остання й сама вважається тим механізмом, за допомогою якого етнічна група "передає себе у спадок” нащадкам [6, 249]. У більш широкому 


\section{ВИКОНАВСЬКА РЕКОНСТРУКЦІЯ ОБРЯДІВ ЯК ОДИН З МЕТОДІВ ТРАНСМІСІЇ НАРОДНОӤ МУЗИЧНОЇ ТРАДИЦІї}

значенні це спосіб переказу інформації (усної традиції) - від людини до людини, від одного соціуму до іншого усним шляхом, шляхом друку, аудіо-, відеозаписів і знову ії повернення до людини $[1,3]$.

Одним із способів фольклорної трансмісії можна вважати реконструкцію як відтворення, відновлення чого-небудь за рештками, описами, що збереглися. Звичайно, реконструкція обряду не може повністю відповідати йому так, як це відбувалося в природньому середовищі, однак можливе його максимальне наближення до останнього. М. Хай називає цей спосіб відтворення фольклору науково-виконавським фольклоризмом, основними методичними і творчими засадами якого $є$ співати і грати так, як в оригіналі, з метою вивчення, популяризації та власної сублімації, духовного очищення-катарсису $[8,17]$. У цьому визначенні поєднані такі характеристики, як вивчення і популяризація, присутні в навчально-просвітницькій діяльності, i сублімація та катарсис, притаманні автентичному фольклорові ${ }^{1}$. Тим самим автор декларує вихід автентичного фольклору за межі традиційного, класичного розуміння способу існування, внаслідок чого межа між термінами автентичний фольклор і фольклоризм розмивається. С. Грица пояснює це новими умовами побутування фольклору і зв'язком фольклору з літературою, який сьогодні став тісніший порівняно з минулими періодами. Вона зазначає, що інсценізації обрядів, звичаїв у репертуарі народних чи професіональних колективів дуже часто здійснюються вже не за автентичними зразками, яких у побуті іноді й немає, а за літературними описами. Якщо така “реставрація" вдала, то вона може послужити поштовхом до подальшого розвитку традиційного обряду, популяризації певної призабутої пісні $[2,37]$.

Реконструкція обрядів календарного та родинного циклів, а кожен обряд є синкретичним за своєю природою дійством, здійснюється за участю співу, інструментальної гри і сукупності всіх інших структурних елементів цілого. Важливою проблемою у цій формі трансмісії в сучасних умовах виявляється якість відтворення обряду, особливо це стосується тих дійств, що відділені від сучасності значним часовим періодом, наслідком чого є відсутність живих свідків, які знають його проведення у природному контексті. До таких обрядів відносяться обжинки,

\footnotetext{
${ }^{1}$ Іншим видом фольклоризму вчений вважає композиторську роботу з автентичними зразками $[8,17]$.

${ }^{2}$ Виконавцями на музичних інструментах виступили: М. Хай - скрипка, Любомир Кушлик - цимбали, Галина Маркович - бубен, Лідія Федоронько - бас; співали: студентський гурт автентичного співу “Ладканка” у складі студентів Інституту музичного мистецтва ДДПУ імені Івана Франка під керівництвом Лідії Федоронько.
}

Молодь і ринок №10 (177), 2019 експедицій у деяких селах Дрогобиччини, ми записали свідчення окремих старожилів, за якими у 50-х роках у колгоспах, в рамках “творення нової обрядовості” проводились обжинки на закінчення збору врожаю. Ми не ставили собі за мету записати детальний перебіг такої композиції, але жінки відтворили наспіви, які виконувались на таких заходах, і ці наспіви за вербальним i музичним текстом були традиційні, з обжинкового обряду. В даному випадку можемо говорити про трансмісію, яка не є реконструкцією в прямому розумінні, адже сам обряд не ніс того змісту, що традиційні обжинки, хоча деякі елементи могли співпадати.

В теперішніх умовах локального середовища обряд обжинок відсутній у пам'яті навіть старожилів, за винятком переказів про нього від попередніх поколінь, а відтак відтворення обряду можливе за матеріалами, які існують у краєзнавчій та науковій літературі.

У 2018 році відомим етномузикологом Михайлом Хаєм вперше була здійснена реконструкція обжинок на Франко-Фесті у обжинки”, свідчить про радше узагальнений характер цього дійства, яке містило елементи 3 різних середовищ Бойківщини. Основним завданням було поставлено відтворення в загальних рисах обжинкової композиції і виконавської манери співу та інструментальної гри. В цілому, відтворення обряду дає уявлення про це старовинне, наповнене символами i ритуалами, дуже важливе в календарній системі святкувань, дійство.

На наступному етапі нами було поставлено за мету здійснити реконструкцію обжинок, матеріал для якої становить фольклор саме 3 села Нагуєвичі. Опис цієї локальної традиції подає Ганна Гром у краєзавчій розвідці про с. Нагуєвичі, в розділі про звичаї, традиції та обряди [3, 155 156], яка є розширеною (чи доповненою) версією першого видання авторки з 1992 р. [4]. На жаль, в праці не подано інформації, від кого автор записувала обряд і тексти, однак можна здогадуватись, що цей варіант вже не $є$ повністю автентичним. Тексти “ведучого” - хлопця, а також господаря і господині, дають підстави думати, що він використовувався у “новій”, радянській на той час, обрядовості для шкільних певної міри було реконструкцісю. Під час наш Нагуєвичах ${ }^{2}$. Назва цього заходу - "Бойківські 


\section{ВИКОНАВСЬКА РЕКОНСТРУКЦІЯ ОБРЯДІВ ЯК ОДИН 3 МЕТОДІВ ТРАНСМІСЇ̈ НАРОДНОЇ МУЗИЧНОЇ ТРАДИЦЇ̈}

або клубних постановок, але водночас він демонструє варіант, більш тісно пов'язаний 3 народною основою. Цікавою є динаміка змін, що прослідковується від першого видання до наступного - так хлопещь у виданні 1992 р. називався ще традиційно - ватаг. Окремі слова в його текстах піддані заміні, зокрема, господарики, в пізнішій версії було замінено на господарi, внаслідок чого порушився віршовий ритм, який у першому виданні більш наближений до народного:

Наш господарик красний

Виростив урожай ясний.

Або:

Дякуємо вам, господарики ясні,

За музиченьки красні. [3, 58]

В композицію обряду вплетено і автентичні ладканкові тексти, на жаль, без музики ${ }^{3}$ Крім того, допущені мікрозміни у деяких словах і не дотримані форми локальної говірки, як, наприклад: дожили ми зарана, у локальному варіанті має бути: дожьили(дожсли)-смо зарана. В цілому, даний опис дає уявлення про локальний ваірант обжинок і може слугувати для використання його в реконструкції обряду.

Про нагуєвицький фольклор, зокрема, музичнообрядовий, існує кілька публікацій наукового рівня, 3 яких достатньо повний у жанровому плані $\epsilon$ збірник, упорядкований В. Соколом [7]. В ньому вміщені сім обжинкових ладканок з окремими коментарями про перебіг обряду, записаних у 1983 році від жінок, які народилися на початку XX ст., а отже, самі були учасницями обжинок [7, 61 67,363 - 364]. Зокрема, зазначено, коли відзначаються обжинки і в який момент обряду яка ладканка виконується. Насправді всі зразки цього жанру, записані в Нагуєвичах, демонструють різні варіанти одного наспіву, які мають один звукоряд в межах кварти, одну структуру $7_{3}$, але відрізняються початковими та серединними інтонаційними зворотами і манерою виконання - або рубатною, або більш простою, тобто змінами імпровізаційного характеру. Порівняння цього наспіву з пастушими та весільними ладканками збірника засвідчує їх єдність і дає підстави стверджувати, що в Нагуєвичах існував один емблемний наспів, який використовувався в різних обрядах - крім обжинкового, у весільному, пастушому тощо. Це типово для мелодій обрядового призначення по цілій Бойківщині, в основі яких лежить певна мелодична матриця, що в кожному локальному

\footnotetext{
${ }^{3}$ Статус опублікованої праці як краєзнавчої розвідки не зобов'язує друкувати ноти.
}

${ }^{4}$ Тепер - Львівська державна музична академія імені Миколи Лисенка. середовищі розспівується 3 відмінами на мікрорівні і таким чином, становить стильову особливість кожного локусу.

Вербальні тексти до ладканок містять повторення смислових блоків, що отримують таким чином значення "рефрену” у обряді. Наприклад текст Дожєли-смо зарана, (2)

Заріжте нам барана.

Барана рогатого (2),

Ми в пана богатого.

зустрічається майже в кожному варіанті. $€$ й інші повтори, але вже зумовлені записом під час різних сеансів від різних виконавиць, в яких зафіксовані важливіші дії в обряді: похід по калину - важливого атрибуту обжинкового вінка ("Idimb дівки по калину”), дії господині (“Нашє господні пишна(2) / За воротенька вийшла”), господаря (“Що наш господар діє (2) / B стодолі просо віє”) тощо.

На відміну від більшості варіантів збірника, останній наспів у розділі обжинкових $[7,67]$ також був записаний раніше, під час експедиції в 1958 р., здійсненої працівниками Львівської консерваторії 3. Штундер і Я. Шустом. Аудіозаписи цієї фольклористичної експедиції та транскрипції 3. Штундер зберігаються у архіві консерваторії і опубліковані [5]. Ці матеріали цінні насамперед можливістю почути автентичну манеру виконання обжинкових наспівів та додатковими текстами, яких немає у вищезазначених публікаціях. Загальновідомо, що манера виконання - це саме той рівень у народномузичних творах, який не піддається фіксації, але він становить невід'ємну частину локального стилю і разом 3 іншими елементами творить той неповторний профіль, що відрізняє його серед інших народномузичних діалектів. Тому для відтворення зразків, з метою максимального наближення до оригіналу, так важливо знати їх звучання. Мелодії ладканкового типу - своєрідні лейтмотиви, знаки, які супроводжували обряди весілля, обжинок, першого вигону худоби, зелених свят тощо. Тому за повної відсутності аудіозразків аналізованого жанру можна опертись на звучання весільних ладканок, які ще присутні хоча б у пасивній пам'яті жінок, позаяк манера виконання цих двох жанрів дуже близька. На щастя, у випадку Нагуєвич маємо можливість слухати і наслідувати наспіви саме обжинкового жанру.

Крім ладканок, в матеріалах експедиції є ще два зразки неладканкового, позаобрядового типу, однак вони виконують певну функцію в обжинках. Це пісні “Ой у полі нивка" та "Ішли женці в поле 
жати", які співаються, коли жінки йдуть в поле. Отже, маємо цікаві свідчення 60-річної давності про проникнення в обряд пісень інших жанрів, в даному випадку за текстом визначаємо їх як лірична в першому випадку та баладна в другому, за мелодією це зразки лірико-побутового жанру. Впродовж XX ст. ці жанри спочатку активно співіснували 3 обрядовими, а потім поступово почали їх заміщувати, про що свідчать результати опитування виконавців сьогодні. Нам неодноразово доводилось фіксувати саме ці пісні, які ідентифікуються як обжинкові і свідчать про зміни в структурі обжинкового обряду.

Таким чином, беручи до уваги найважливіші джерела обжинкового фольклору села Нагуєвичі, можемо визначити подальшу послідовність етапів реконструкції. 3 усіх мелодичних варіантів варто вибрати ті, які найбільше відрізняються між собою для того, щоб презентувати цей ряд якомога різноманітніше. Звичайно, це буде відмінність подібностей, бо в основі всіх є один інваріант, але такою є особливість варіантної природи ладканкового типу в односередовищному горизонтальному зрізі 5 . 3 усіх вербальних текстів потрібно змонтувати послідовність тих, які не повторюються, хоча текст “Дожьили-смо зарана..." можна використати, як вже згадувалося, в якості рефрена. Маючи до того ж коментарі про послідовність обряду обжинок, можна відтворити все 3 достовірністю максимального наближення до оригіналу, проте, на нашу думку, найважливішою у концепті реконструкції $\epsilon$ манера пісенного та інструментального виконання і достатня точність мелодичного та мовного змісту.

Щодо реконструкції інших обрядів українського фольклору, зокрема, колядково-щедрівкового, гаївкового чи весільного, з огляду на їх часткову збереженість у сучасному локальному середовищі, то вона має більші можливості у використанні тих елементів, які ще існують якщо не в активному, то хоча б у пасивному стані, чим можна керуватись при виборі для відтворення того чи іншого обряду. У всіх випадках важливо зазначити, що відтворення музичного фольклору у вторинних формах потребує особливого відношення і знання системи зсередини, тому реконструкція, як одна 3 форм трансмісії фольклору, повинна використовуватись дуже обережно. Ми підтримуємо твердження С. Грици про те, що застосування фіксованих, сценічних форм фольклору порушує його генетичні, автентичні основи [2, 147]. Надмірне чи невластиве використання таких елементів може призвести до небажаних наслідків у сфері автентичної народної творчості. Водночас, тонке, зі знанням локальних особливостей манери виконання та з використанням спонтанних форм, відтворення народних обрядів допоможе зберегти, продовжити і розвинути те, що $\epsilon$ найціннішим у нашій культурі.

Висновки. У процесі трансмісії народномузичних обрядових традицій реконструкція виконує одну 3 вагомих функцій - вона має здатність сприяти відновленню елементів локальної культури, не тільки музичних, але й ментальних, етнографічних тощо, і таким чином підживлювати та доповнювати національну культуру як в цілому, так і в іiі місцевих різновидах. Для того, щоб реконструкція була успішною, необхідно враховувати всі особливості народномузичної системи і фольклору в цілому, тому до ії реалізації повинні залучатись фахівці, і в першу чергу етномузикологи.

\section{ЛІТЕРАТУРА}

1. Грица С. Трансмісія фольклорної традиції. Етномузикологічні розвідки. Київ-Тернопіль, 2002. $236 \mathrm{c}$.

2. Грица С. Фольклор у просторі та часі. Вибрані статті. Тернопіль, 2000. 228 с.

3. Гром Г. Нагуєвичі. Дрогобич, 2002.

4. Гром Г.П. Нагуєвичі - батьківщина Івана Франка. Дрогобич, 1992. 68 с.

5. Добрянська Л. Експедиція Львівської консерваторії в село Івана Франка. Етномузика / Упор. Б. Луканюк. Львів, 2007. Число 2: Збірка статей та матеріалів на честь Івана Франка С. 123 $-147$.

6. Народні пісні з батьківщини Івана Франка. Зібрав та упорядкував В.Сокіл. Львів, 2003. 407 с.

7. Сміт Ентоні Д. Культурні основи націй. Ієрархія, заповіт і республіка. Наукове видання. Київ, 2010.312 c.

8. Хай М. Музично-інструментальна культура українців (фолкльорна традиція). КиївДрогобич, 2007. 537 с.

\section{REFERENCES}

1. Hrytsa, S. (2002). Transmisija folklornoji tradyciji: etnomuzykolohichni rozvidky [Transmission of folklore tradition: secret services of ethnic musicology]. (Ed.). M.T. Rylskyij. Kyiv - Ternopil, 236 p. [in Ukrainian]

2. Hrytsa, S. (2000). Folklor u prostori i chasi

${ }^{5}$ Наспіви, зафіксовані у 1958 р., тільки підтверджують правило. 
[Folklore in space and time: the chosen articles].

(Ed.). S. Smoliak. Ternopil, 228 p. [in Ukrainian].

3. Hrom, H. (2002). Nahujevychi [Nahujevychi]. Drohobych. [in Ukrainian].

4. Hrom, H. (1992). Nahujevychi-Bat'kivshchyna Ivana Franka [Nahujevychi - motherland of Ivan Franko]. 68 p.[in Ukrainian]

5. Dobrianska, L.(2007). Expedytsija Lvivskoji konservatoriji v selo Ivana Franka [Expedition of the Lviv conservatory in the village of Ivan Franko]. Ethnomusic (Ed.). Bohdan Lukaniuk. Lviv, pp. 123 - 147. [in Ukrainian].
6. Narodni pisni z butkivshchyny Ivana Franka (2003). [Folk songs from the motherland of Ivan Franko]. (Ed.). Vasyl Sokil. Lviv, 407 p. [in Ukrainian]. 7. Smith Entoni, D. (2010). Kulturni osnovy natsij. Ijerurkhija, zapovit i respublika [The cultural Foundations of Nations: Hierarchy, Covenant, and Republik]. Kyiv, 312 p. [in Ukrainian].

8. Khaj, M. (2007). Muzychno-instrumentalna kultura ukrajintsiv (folklorna tradycija) [Musically-instrumental culture of Ukrainians (folklore tradition)]. Kyiv - Drohobych. 537 p. [in Ukrainian].

Стаття надійшла до редакції 02.08.2019

УДК 373.3.091.322

DOI:

Іван Василиків, кандидат педагогічних наук, старший викладач кафедри математики, інформатики та методики їх викладання у початковій школі, магістр факультету початкової та мистецької освіти Дрогобицького державного педагогічного університету імені Івана Франка

\section{ЗАСТОСУВАННЯ ІНФОРМАЦЙНИХ ТЕХНОЛОГІЙ ДЛЯ РОЗВИТКУ ТВОРЧОГО МИСЛЕННЯ УЧНІВ НА УРОКАХ І В ПОЗАКЛАСНІЙ РОБОТІ В ПОЧАТКОВІЙ ШКОЛІ}

У статті досліджується те, щуо в освіті нашої краӥни існує реформа, яка спрямована на оновлення ї̈ змісту, на вдосконалення технології освіти. Це процес, щуо триває, оскільки він пов'язаний з прогресом суспільства і на кожному етапі розвитку конкретні завдання для школи визначаються на різних рівнях.

Центром ицих процесів у середній школі є особистість вчителя. Без підготовки нового покоління вчителів, які піднімуть свій професійний та культурний рівень, неможливо внести принципові зміни в освіту. Особлива увага приділяється вчителям початкових класів, оскільки вік учнів 1 - 4 класів, на думку психологів, - ие вік, у якому вони розвивають певні риси особистості, пов 'язані з психічним розвитком.

Ключові слова: інформачійні технологї; початкова школа; презентація; творче мислення.

Puc. 3. Лim. 10.

Ivan Vasylykiv, Ph.D.(Pedagogy), Senior Lecturer of the Mathematics, Computer Science and Teaching Methods in Elementary School Department, Master of Arts in Elementary and Art Education Drohobych Ivan Franko State Pedagogical University

\section{THE IMPLEMENTATION OF INFORMATION TECHNOLOGIES FOR DEVELOPMENT OF CREATIVE THINKING OF PUPILS AT THE LESSONS AND DURING AFTER CLASS ACTIVITIES IN PRIMARY SCHOOL}

The author states that the reform in education of our country aimed at updating its content and improving the technology of education. It is an ongoing process because it is linked to the progress of society and at each stage of development; specific tasks for the school are defined at different levels.

The center of these processes in high school is the personality of the teacher. Without the preparation of a new generation of teachers who will raise their professional and cultural levels, it is impossible to make fundamental changes in education. Particular attention is paid to elementary school teachers, because the age of students of grades $1-4$, according to psychologists, is the age at which they develop certain personality traits related to mental development.

An indispensable component of the teachers' modern education is mastering the modern technologies of obtaining and disseminating new information to students. Thirty years ago, both the student and the teacher lived in a rather slow world with stable programs, textbooks, and the state system of providing textbooks from the development of the entire course of lessons, instructional films, movies, educational television and more. On the one hand, it provided for the necessary and, on average, a sufficiently good organization of the educational process, on the other, it did not contribute to the teacher's creativity and autonomy in the student's learning and impeded his initiative. 